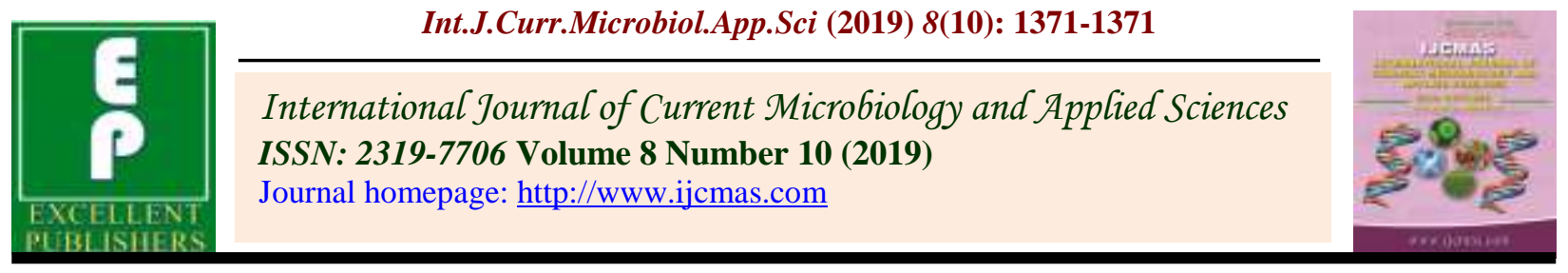

Original Research Article

https://doi.org/10.20546/ijcmas.2019.810.159

\title{
Management of Sorghum Anthracnose caused by Colletotrichum graminicola (Ces.) Wilson
}

\author{
R. N. Bunker*, N. S. Tanwar and S. K. Aggarwal \\ Department of Plant Pathology, Rajasthan College of Agriculture Maharana Pratap \\ University of Agriculture and Technology, Udaipur-313001, Rajasthan, India \\ *Corresponding author
}

\section{A B S T R A C T}

\section{Keywords}

Colletotrichum graminicola,

Sorghum, Nem oil, Fungicides

\section{Article Info}

Accepted:

12 September 2019

Available Online:

10 October 2019
Anthracnose of sorghum caused by Colletotrichum graminicola (Glomerella graminicola) is an important sorghum malady in India. The pathogen exhibits good tolerance to varied ranges of agroclimatic conditions over the globe and causes substantial economic losses. The present investigation was carried out during 2016 and 2017 kharif season at Rajasthan College of Agriculture, Udaipur with aimed to find out a sustainable management of anthracnose by using different fungicides and botanical (Neem oil) either individually or in combination. Different treatments were tested in the field growing moderately susceptible dual purpose sorghum cultivar Raj. Chari-2. The two years pooled data results were revealed that application of Carbendazim 50\% wp @ 0.2\% seed treatment (ST) + two foliar spray of neem oil @ $0.5 \%$ at 7 days interval showed minimum disease (PDI) $24.0 \%$ with maximum 67.14 per cent disease control (PEDC) and highest (32.35 q/ha and $231.82 \mathrm{q} / \mathrm{ha}$ ) grain and fresh green fodder yield respectively compare to other treatments over control. Followed by this seed treatment (ST) with Saaf (Carbendazim 12\% + Mancozeb 63\% wp) @ $0.3 \%$ + two foliar spray of neem oil @ 0.5\% was also found effective for the management sorghum anthracnose. Application of botanicals seems batter to reduce the chemical residual effect in fodder and grains. Such treatment signifies the synergistic action of chemicals and botanicals in combined application against pathogens.

\section{Introduction}

Sorghum [Sorghum bicolr (L.) Moench] ranks fifth, among the world's cereals in the order of wheat, maize, rice and barley. It is used primarily as animal feed in the United States of America, Australia, Brazil and other developed nations and mainly grown for fodder purpose. Sustainable sorghum cultivation diseases are the major constraint in realizing proper yield potentials (ICRISAT, 1980). Though sorghum is a marginal crop in Rajasthan and plant protection is usually not a priority for the farmers, but in seed production plots and for cattle feeding, the disease has to be contained to mitigate the losses caused by 
this pathogen. Sorghum crop attacked from several foliar pathogens, causing different types of leaf spot diseases. Anthracnose is an important melody of sorghum that cause stalk rot and foliar damage and affects all plant parts including stem, leaf, peduncle, inflorescence that directly and indirectly affect crop productivity and quality of produce resulted yield losses can occur up to 70 per cent (Ali and Warren, 1992; Singh and Boora, 2008; Thomas et al., 1996; Thakur and Mathur, 2002a and 2007b). Most of the known work on management of anthracnose through fungicides has been done on sorghum (Pinto, 2003; Gwary and Asala, 2006). Beside this, spray of chemicals for manage this disease is decreases profit margins of low cash-input forage production systems and increases the risk of residual effects. In this, connection to reduce the dependence on fungicides, the present investigations were under taken through seed treatment with fungicide and foliar spray of neem oil for eco-friendly management of foliar diseases.

\section{Materials and Methods}

The field experiment was conducted during kharif (rainy season) 2016 and 2017 at Agronomy farm, RCA, Udaipur. The experiment was laid out in randomized block design (RBD) heaving4m x $4 \mathrm{~m}$ size plots in three replications. Seeds of susceptible forage sorghum cultivar "Raj. Chari-2" was sown at $(45 \mathrm{~cm} \times 15 \mathrm{~cm})$ row to row and plant to plant distance after treated with the calculated dose of each fungicides and botanical (neem oil). Recommended agronomical practices for fertilizers (N-80, P-40 \& K-40 kg ha $\left.{ }^{-1}\right)$ and insect management (furrow application of carbofuran (Furadan) granules @ 5g/5 m row and weed management, (pre-germination spray of (atrazine) @ $0.5 \%$ and mechanical removal were followed. To create ephytotic condition in field inoculums of pathogen (Colletotrichum graminicola) was multiplied on autoclaved sorghum grains (Whitehead, 1957).

\section{Application of fungicides and botanical (neem oil)}

There were different seven treatments were applied individually as seed treatment alone as well as in various combinations viz, Dithane M-45@0.3\%, (2.66g/kg), Carbendazim 50 wp @ 0.1\% (2g/kg), Saaf (Carbendazim 12\% + Mancozeb 63\% wp) @ 0.3\% (2.66g/kg) and botanical (neem oil) @ 0.5\% (5ml/ liter)were applied individually in various combinations viz; Carbendazim 50\% wp @ 0.3\%, seed treatment + Neem oil @ $0.5 \%$ spray, Saaf (Carbendazim 12\% + Mancozeb 63\% wp) @ $0.3 \%,+$ Neem oil @0.5\% spray and Dithane M-45@0.3\%,+Neem oil @0.5\% spray. The treated seeds were allowed to air dry before sowing. The spray of neem oil was repeated twice at 7 days intervals just after initiation of disease symptoms under ephiphytotic conditions.

\section{Mass multiplication and application of inoculums}

Culture of C.graminicola isolated from infected leaves of sorghum plant was multiplied on autoclaved sorghum grains. The sorghum grains were soaked in water overnight and washed with tap water and $150 \mathrm{~g}$ grains were added in $500 \mathrm{ml}$ conical flask and then autoclaved at a pressure of $1.045 \mathrm{~kg} \mathrm{~cm}^{-2}$ for one hour. The overall growth of the seven days old pure culture of $C$. graminicola was aseptically homogenized in $10 \mathrm{ml}$ sterile water with a sterilized needle and $5 \mathrm{ml}$ of homogenized culture was used for seeding each flask. Inoculated flasks were incubated at $28 \pm 2^{0} \mathrm{C}$ and were shaken manually every alternate day to obtain uniform distribution of fungal growth on sorghum grains and to prevent caking. After twelve to fifteen days, from these sorghum grains, spore suspension 
was prepared by blending the grains with distilled water (1:1) and filtering through muslin cloth. The desired inoculum densities were checked under microscope for sufficient conidia in prepared suspension. The spore suspension was spray-inoculated on 28-daysold plants with the help of hand held sprayer to the run off level. The inoculation was done during favourable environmental conditions and presence sufficient moisture and even followed by a heavy irrigation to provide adequate moisture for infection.

\section{Data recording}

Observations of disease development and disease severity were recorded on a standard disease rating scale (1-9 score) where, $1=0$ to $<1$ per cent leaf area infected, $2=1-5$ per cent leaf area infected, $3=6-10$ per cent leaf area infected $4=11-20$ per cent area infected and 5 $=21-30$ per cent area of leaf infected, $6=31$ 40 per cent leaf area infected, $7=41-50$ per cent leaf area infected, $8=51-75$ per cent leaf area infected and 9=75-100 per cent leaf area infected.

The per cent disease index (PDI) and per cent efficacy of disease control (PEDC) was calculated by using following formula given by Mc Kinney, 1923; Chester 1959; Wheeler, 1969:

Per cent disease index (PDI)

Sum of all individual disease rating

Total no. of plants assessed* Max rating

PEDC

Infection index in control

- Infection index in treatment

Infection index in control

Grain yield and fodder yield of the plots was recorded in $\mathrm{Kg} /$ plot and same were determined in $\mathrm{q} /$ ha by harvesting the plots individually for each treatment.

\section{Results and Discussion}

The efficacy of fungicides and botanical were tested individually as seed treatments and their integration for two consecutive years. Combined application of carbendazim 50\% wp@ $0.1 \%$ seed treatment + neem oil @ $0.5 \%$ spray for two times at 7 days intervals just after initiation of disease symptoms effectively suppressed the disease and recorded the minimum PDI $(25.5 \%)$ with maximum (66.7) per cent disease control with highest (31.75 q/ha) and (235.52 q/ha) fresh fodder yield respectively, in 2016 compare to other treatments and control.

Followed by Saaf (Carbendazim 12\% + Mancozeb 63\% wp) @ 0.3\% and Neem oil @ $0.5 \%$ foliar spray was also found effective with minimum PDI (30.0\%) and maximum (60.8) per cent disease control with (28.0 q/ha) grain yield and $(220.31 \mathrm{q} / \mathrm{ha})$ fodder yield respectively, for the management sorghum anthracnose (Table 1).

Although, individual seed treatment of fungicides and botanical (neem oil) were significantly effective to suppress the disease but, it was not effective for longer period due to less persistence period.

Although, in 2017 the disease severity was slightly lower compare to 2016, but the syngersitic Combined application of Carbendazim 50\% wp @ 0.1\% seed treatment + Neem oil@0.5\% spray for two times at 7 days intervals just after initiation of disease symptoms effectively suppressed the disease and recorded the minimum PDI (22.5\%) with maximum (66.7) per cent disease control with highest (31.75 q/ha) grain yield and (235.52 $\mathrm{q} / \mathrm{ha}$ ) fresh green fodder yield respectively, in 2017-18 compare to other treatments and control. 
Table.1 Relative efficacy of seed treatment and foliar spray of promising fungicides and botanical on sorghum anthracnose (2016)

\begin{tabular}{|c|c|c|c|c|c|c|c|}
\hline $\begin{array}{l}\text { S. } \\
\text { No. }\end{array}$ & Fungicide/botanical & $\begin{array}{l}\text { Per cent } \\
\text { disease } \\
\text { index } \\
\text { PDI* }\end{array}$ & PEDC* & $\begin{array}{l}\text { Grain yield } \\
\text { (Kg/plot) }\end{array}$ & $\begin{array}{c}\text { Grain } \\
\text { yield } \\
\text { (q/ha) }\end{array}$ & $\begin{array}{c}\text { Fresh fodder } \\
\text { yield } \\
\text { (Kg/plot) }\end{array}$ & $\begin{array}{l}\text { Fresh fodder } \\
\text { yield (q/ha) }\end{array}$ \\
\hline 1. & $\begin{array}{c}\text { Dithane M-45 [mancozeb] @ } \\
0.3 \% \text { (ST) }\end{array}$ & $\begin{array}{c}37.0 \\
(37.5)\end{array}$ & $\begin{array}{l}51.63 \\
(45.6)\end{array}$ & 3.16 & 19.77 & 29.92 & 191.23 \\
\hline 2. & $\begin{array}{c}\text { Carbendazim 50wp @ 0.1\% seed } \\
\text { treatment (ST) }\end{array}$ & $\begin{array}{l}33.75 \\
(35.1)\end{array}$ & $\begin{array}{l}55.88 \\
(47.4)\end{array}$ & 3.54 & 23.99 & 32.33 & 207.0 \\
\hline 3. & Saaf @ 0.3\% seed treatment (ST) & $\begin{array}{c}35.0 \\
(36.2)\end{array}$ & $\begin{array}{c}54.2 \\
(46.48)\end{array}$ & 3.84 & 22.15 & 31.00 & 200.0 \\
\hline 4. & $\begin{array}{c}\text { Neem oil } 0.5 \% \text { seed treatment } \\
(\mathrm{ST})\end{array}$ & $\begin{array}{c}41.5 \\
(40.1)\end{array}$ & $\begin{array}{c}45.8 \\
(42.6)\end{array}$ & 2.87 & 17.92 & 28.55 & 182.33 \\
\hline 5. & $\begin{array}{c}\text { Dithane M-45 @ 0.3\% (ST)+ } \\
\text { Neem oil } 0.5 \%(\mathrm{FS})\end{array}$ & $\begin{array}{c}32.0 \\
(34.4)\end{array}$ & $\begin{array}{c}58.1 \\
(49.7)\end{array}$ & 4.19 & 26.17 & 34.50 & 215.63 \\
\hline 6. & $\begin{array}{c}\text { Carbendazim } 50 \text { wp @ } 0.1 \% \\
(\mathrm{ST})+\text { Neem oil } 0.5 \% \text { (FS) }\end{array}$ & $\begin{array}{c}25.5 \\
(30.3)\end{array}$ & $\begin{array}{c}66.7 \\
(54.7)\end{array}$ & 5.08 & 31.75 & 37.68 & 235.52 \\
\hline 7. & $\begin{array}{c}\text { Saaf @ } 0.3 \% \text { seed treatment + } \\
\text { Neem oil } 0.5 \%(\mathrm{FS})\end{array}$ & $\begin{array}{c}30.0 \\
(33.2)\end{array}$ & $\begin{array}{c}60.8 \\
(51.2)\end{array}$ & 4.48 & 28.00 & 35.25 & 220.31 \\
\hline 8. & $\begin{array}{l}\text { Control (pathogen inoculated } \\
\text { plot) }\end{array}$ & $\begin{array}{l}76.5 \\
(61.0)\end{array}$ & 0.0 & 2.2 & 13.75 & 26.67 & 166.67 \\
\hline & $\mathrm{CV}$ & 2.32 & 2.57 & 3.90 & 3.90 & 4.56 & 14.21 \\
\hline & $\mathrm{CD}(P=0.05)$ & 1.50 & 1.90 & 0.25 & 1.56 & 2.15 & 4.56 \\
\hline
\end{tabular}

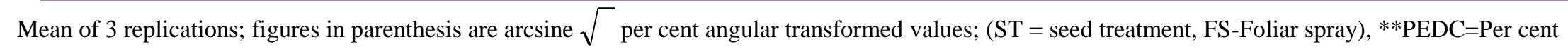
efficacy of disease control; PDI*=Per cent disease index; Plot size $4 \times 4 \mathrm{~m}=16 \mathrm{~m} 2$, 
Table.2 Relative efficacy of seed treatment and foliar spray of promising fungicides and botanical on sorghum anthracnose (2017)

\begin{tabular}{|c|c|c|c|c|c|c|c|}
\hline $\begin{array}{l}\text { S. } \\
\text { No. }\end{array}$ & Fungicide/botanical & $\begin{array}{c}\text { Per cent } \\
\text { disease } \\
\text { index } \\
\text { PDI* }\end{array}$ & PEDC* & $\begin{array}{l}\text { Grain yield } \\
\text { (Kg/plot) }\end{array}$ & $\begin{array}{l}\text { Grain yield } \\
\text { (q/ha) }\end{array}$ & $\begin{array}{l}\text { Fresh fodder } \\
\text { yield }(\mathrm{Kg} / \mathrm{plot})\end{array}$ & $\begin{array}{l}\text { Fresh fodder } \\
\text { yield (q/ha) }\end{array}$ \\
\hline 1. & $\begin{array}{c}\text { Dithane M-45 [mancozeb] @ } \\
0.3 \%(\mathrm{ST})\end{array}$ & $\begin{array}{c}35.0 \\
(36.27)\end{array}$ & $\begin{array}{c}49.6 \\
(44.78)\end{array}$ & 3.20 & 20.10 & 30.67 & 191.94 \\
\hline 2. & $\begin{array}{c}\text { Carbendazim 50wp @0.1\% seed } \\
\text { treatment (ST) }\end{array}$ & $\begin{array}{c}31.2 \\
(34.14)\end{array}$ & $\begin{array}{c}54.62 \\
(47.45)\end{array}$ & 3.80 & 23.75 & 34.08 & 213.00 \\
\hline 3. & Saaf@0.3\% seed treatment (ST) & $\begin{array}{c}33.0 \\
(34.41)\end{array}$ & $\begin{array}{c}53.18 \\
(46-51)\end{array}$ & 3.50 & 21.87 & 32.95 & 205.93 \\
\hline 4. & $\begin{array}{c}\text { Neem oil } 0.5 \% \text { seed treatment } \\
\text { (ST) }\end{array}$ & $\begin{array}{c}39.0 \\
(38.64)\end{array}$ & $\begin{array}{c}43.85 \\
(41.47)\end{array}$ & 2.78 & 17.37 & 29.08 & 181.75 \\
\hline 5. & $\begin{array}{c}\text { Dithane M-45 @ 0.3\% (ST)+ } \\
\text { Neem oil } 0.5 \%(\mathrm{FS})\end{array}$ & $\begin{array}{c}29.10 \\
(33.01)\end{array}$ & $\begin{array}{c}57.19 \\
(49.20)\end{array}$ & 4.69 & 29.31 & 35.50 & 221.88 \\
\hline 6. & $\begin{array}{c}\text { Carbendazim } 50 \text { wp @ } 0.1 \% \text { (ST) } \\
\text { + Neem oil 0.5\% (FS) }\end{array}$ & $\begin{array}{c}22.5 \\
(28.31)\end{array}$ & $\begin{array}{c}67.51 \\
(55.31)\end{array}$ & 5.58 & 34.87 & 38.20 & 238.75 \\
\hline 7. & $\begin{array}{c}\text { Saaf @ 0.3\% seed treatment + } \\
\text { Neem oil 0.5\% (FS) }\end{array}$ & $\begin{array}{c}27.5 \\
(31.63)\end{array}$ & $\begin{array}{c}60.67 \\
(50.99)\end{array}$ & 4.98 & 31.13 & 36.50 & 228.13 \\
\hline 8. & $\begin{array}{l}\text { Control (pathogen inoculated } \\
\text { plot) }\end{array}$ & $\begin{array}{c}69.5 \\
(56.49)\end{array}$ & 0.0 & 2.10 & 13.12 & 26.0 & 162.50 \\
\hline & $\mathrm{CV}$ & 2.52 & 2.97 & 3.89 & 3.89 & 2.64 & 9.60 \\
\hline & $\mathrm{CD}(P=0.05)$ & 1.76 & 1.91 & 0.27 & 1.68 & 1.51 & 2.54 \\
\hline
\end{tabular}

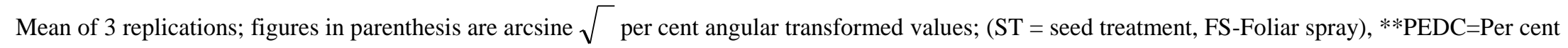
efficacy of disease control; PDI*=Per cent disease index; Plot size $4 \times 4 \mathrm{~m}=16 \mathrm{~m} 2$, 
Table.3 Relative efficacy of seed treatment and foliar spray of promising fungicides and botanical on sorghum anthracnose (pooled value 2016 and 2017)

\begin{tabular}{|c|c|c|c|c|c|c|c|}
\hline S.No. & $\begin{array}{l}\text { Fungicide/botanical with } \\
\text { concentration }\end{array}$ & $\begin{array}{c}\text { Per cent } \\
\text { disease } \\
\text { index } \\
\text { PDI* }\end{array}$ & PEDC* & $\begin{array}{l}\text { Grain yield } \\
\text { (Kg/plot) }\end{array}$ & $\begin{array}{c}\text { Grain } \\
\text { yield } \\
\text { (q/ha) }\end{array}$ & $\begin{array}{c}\text { Fresh } \\
\text { fodder yield } \\
\text { (Kg/plot) }\end{array}$ & $\begin{array}{l}\text { Fresh } \\
\text { fodder } \\
\text { yield } \\
\text { (q/ha) }\end{array}$ \\
\hline 1. & $\begin{array}{c}\text { Dithane M-45 [mancozeb] @ } \\
0.3 \%(\mathrm{ST})\end{array}$ & $\begin{array}{c}36.0 \\
(36.87)\end{array}$ & $\begin{array}{c}50.63 \\
(45.36)\end{array}$ & 3.13 & 19.56 & 31.29 & 195.58 \\
\hline 2. & $\begin{array}{c}\text { Carbendazim } 50 \text { wp @ 0.1\% } \\
\text { seed treatment (ST) }\end{array}$ & $\begin{array}{l}32.47 \\
(34.0)\end{array}$ & $\begin{array}{c}55.52 \\
(47.61)\end{array}$ & 3.77 & 23.56 & 33.04 & 206.50 \\
\hline 3. & $\begin{array}{c}\text { Saaf @ 0.3\% seed treatment } \\
(\mathrm{ST})\end{array}$ & $\begin{array}{c}34.0 \\
(35.6)\end{array}$ & $\begin{array}{c}53.45 \\
(47.01)\end{array}$ & 3.44 & 21.15 & 32.04 & 200.51 \\
\hline 4. & $\begin{array}{c}\text { Neem oil } 0.5 \% \text { seed treatment } \\
\text { (ST) }\end{array}$ & $\begin{array}{c}40.2 \\
(39.37)\end{array}$ & $\begin{array}{c}44.81 \\
(42.57)\end{array}$ & 2.86 & 17.89 & 28.00 & 175.00 \\
\hline 5. & $\begin{array}{c}\text { Dithane M-45 @ } 0.3 \%(\mathrm{ST})+ \\
\text { Neem oil } 0.5 \%(\mathrm{FS})\end{array}$ & $\begin{array}{c}31.7 \\
(34.29)\end{array}$ & $\begin{array}{c}56.39 \\
(48.67)\end{array}$ & 4.44 & 27.74 & 35.00 & 218.75 \\
\hline 6. & $\begin{array}{l}\text { Carbendazim } 50 \text { wp @ 0.1\% } \\
(\mathrm{ST})+\text { Neem oil 0.5\% (FS) }\end{array}$ & $\begin{array}{c}24.0 \\
(29.32)\end{array}$ & $\begin{array}{c}67.14 \\
(55.03)\end{array}$ & 5.33 & 32.35 & 37.09 & 231.82 \\
\hline 7. & $\begin{array}{c}\text { Saaf@0.3\% seed treatment + } \\
\text { Neem oil } 0.5 \%(\mathrm{FS})\end{array}$ & $\begin{array}{c}28.7 \\
(32.42)\end{array}$ & $\begin{array}{c}60.57 \\
(51.11)\end{array}$ & 4.95 & 30.93 & 36.72 & 229.53 \\
\hline \multirow[t]{3}{*}{8.} & $\begin{array}{l}\text { Control (pathogen inoculated } \\
\text { plot) }\end{array}$ & $\begin{array}{c}73.0 \\
(58.75)\end{array}$ & 0.0 & 2.11 & 13.18 & 24.83 & 155.18 \\
\hline & $\mathrm{CV}$ & 2.16 & 2.18 & 3.90 & 3.90 & 3.71 & 8.99 \\
\hline & $\mathrm{CD}(P=0.05)$ & 1.11 & 1.25 & 0.20 & 1.27 & 1.66 & 3.71 \\
\hline
\end{tabular}

Mean of 3 replications; figures in parenthesis are arcsine $\sqrt{ }$ per cent angular transformed values; (ST $=$ seed treatment, FS-Foliar spray), **PEDC=Per cent efficacy of disease control; PDI*=Per cent disease index; Plot size 4x4 m= 16 m2 
Followed by Saaf (Carbendazim 12\% + Mancozeb 63\% wp) @0.3\% and Neem oil @ $0.5 \%$ foliar spray was found effective with minimum PDI (27.7\%) and maximum (60.67) per cent disease control with $(28.0 \mathrm{q} / \mathrm{ha})$ grain yield and $(220.31 \mathrm{q} / \mathrm{ha})$ fodder yield respectively, over control for the management sorghum anthracnose (Table 2).

Although, individual seed treatment of fungicides and botanical (neem oil) were significantly effective for suppress the disease but it was not effective for longer period due to less persistence period. In this year maximum $69.5 \%$ disease (PDI) and minimum $13.12 \mathrm{q} / \mathrm{ha}$ grain and $162.50 \mathrm{q} / \mathrm{ha}$ green fodder yield was recorded (Table 2).

\section{Pooled data results}

The two years pooled data analysis reveals of field trials conducted on "Raj. Chari-2" under inoculated conditions, indicate that combined application of Carbendazim 50\% wp @ 0.1\% seed treatment + Neem oil @ 0.5\% spray for two times at 7 days intervals just after initiation of disease symptoms effectively suppressed the disease with minimum PDI (24.0\%) disease and maximum (67.14) per cent disease control and obtained highest (32.5 $\mathrm{q} / \mathrm{ha})$ grain yield and (231.82 q/ha) green fodder yield respectively, compare to other treatments and control. Followed by Saaf (Carbendazim 12\% + Mancozeb 63\% wp) @ $0.3 \%$ and Neem oil @ $0.5 \%$ was found effective compare to other treatments and control.

Whereas, in control (pathogen inoculated plots) minimum $13.18 \mathrm{q} / \mathrm{ha}$ grain and 155.18 $\mathrm{q} /$ ha green fodder yield obtained (Table 3).

In control plots the pooled per cent disease index (PDI) of two years was recorded maximum $73.0 \%$ and minimum $13.18 \mathrm{q} / \mathrm{ha}$ grain and $155.18 \mathrm{q} / \mathrm{ha}$ green fodder yield respectively (Table 3). Suppression of anthracnose through application of individual seed treatment of fungicides; Carbendazim 50 wp; Carbendazim 12\% + Mancozeb 63\% wp (Saaf) and Dithane M-45 [mancozeb] resulted in higher disease severity $(32.47 ; 34.0$ and $36.0 \%)$ and lower $(23.56 ; 21.15$ and 19.56 q/ha.) grain and (206.5; 200.51 and195.58 $\mathrm{q} / \mathrm{ha}$.) fresh fodder yield respectively, has been obtained.

Efficacy of carbendazim, prochloraz, benomyl and azoxystrobin has been reported with smallest incidence of $C$. graminicola on seeds (Pinto; 2003) and suppression of sorghum anthracnose $(C$. sublineolum) by seed treatment of metalaxyl and thiram followed by the spraying of either of the foliar fungicides benomyl, Dithane M-45 [mancozeb] and carbendazim in field (Gwary and Asala 2006).

In the field trials conducted on "Raj. Chari-2" under inoculated conditions, maximum reduction in disease severity $(67.14 \%$ disease control) and increased yield of grain and fodder was obtained with integration of seed treatment with carbendazim and foliar spray of botanical neem oil over the inoculated untreated control.

There were various reports are available that integrated treatments of seedt treatment with fungicides and foliar spray of botanical (Neemoil and leaf extract) fared better than the individual one for suppression of $C$. gaminicola in sick-plots (Bdliya et al., 2009; Jadhav et al., 2013). Although, the botanical in general less effective as compared to fungicides but, their integration with fungicides showed better results in field condution, and may be used for reducing dependency on fungicides.

Further, more diverse types of botanicals and foliar biocontrol agents need to be evaluated for developing eco-friendly and sustainable approach for management of this disease. 


\section{References}

Ali, M. E. K. and Warren, H. L. 1992. Anthracnose of sorghum. In: Sorghum and millets diseases: A second world review Patancheru, India: ICRISAT. Milliano W. A. J. De, Frederiksen, R. A. and Bengston G. D. (Eds.) P. 203-208.

Bdliya, B. S., Kolo, A. K. and Anaso, A. B. 2009. Efficacy of seed treatment with apron star $42 \mathrm{WS}$ and foliar application of emulsified neem (Azadirachtaindica) seed oil in the control of sorghum (Sorghum bicolar L. Moench) anthracnose in the Sudan savannah of Nigeria. Archives of Phytopathology and Plant Protection. 42 : 1118-1125.

Casela, C.R. and Frederiksen, R.A. 1993. Survival of $C$. graminicola sclerotia in sorghum stalk residues. Plant Disease.77: 773-775

Chester, K. S. 1959. How sick is the plant? In "Plant Pathology an Advances Treaties" (Eds. J.G. Horsfall and A.E. Dimond). Academic Press, New York. 1: 199-242.

Gwary, D. M. and Asala, S. W. 2006. Costbenefit of fungicidal control of anthracnose on sorghum in Northern. Nigeria. International Journal of Agriculture and Biology. 8: 306-308.

ICRISAT (International Crops Research Institute for the semi-arid tropics) 1980. In Proceedings of the International Workshop on Sorghum Diseases held at Patancheru, A.P.-502324, India.P. 465

Jadhav, G. K., Johnson, N. and Rajasab, A. H. 2013. Evaluation of neem leaf extract against anthracnose, leaf blight and rust diseases of sorghum. research and reviews. Journal of Agricultural Science \& Technology. 2: 2278-2206.

Mc Kinney, H. N. 1923. Influence of soil temperature and moisture on infection of wheat seedlings by Helminthosporium sativum. J. Agric. Res. 26: 195-217.

Pinto, N. F. J. de. A. 2003. Chemical control of the anthracnose (C. graminicola) of sorghum. RevistaBrasileira de Milho e Sorgo. 2: 148-152.

Singh, M. and Boora, K. S. 2008. Molecular characterization of anthracnose resistance gene in sorghum. Plant Genomics and Bioinformatics. P.373388.

Thakur, R.P. and Mathur, K. 2000. In: Anthracnose. Compendium of Sorghum Diseases. The American Phytopathological Society, St. Paul, MN, USA. Frederiksen R.A. and Odvody, G.N. (Eds.).

Thakur, R. P. and Mathur, K. (2007). Anthracnose. In:Screening Techniques for Sorghum Diseases. Information Bulletin No. 76. Patancheru 502 324, Andhra Pradesh, India: International Crops Research Institute for the SemiArid Tropics. P.16-23.

Thomas, M.D., Sissoko, I. and Sacko, M. 1996. Development of leaf anthracnose and its effect on yield and grain weight of sorghum in West Africa. Plant Dis. 80:151-153.

Wheeler, B. E. J. 1969. An Introduction to Plant Diseases. John Wiley \& Sons Ltd., London. P.301.

\section{How to cite this article:}

Bunker, R. N., N. S. Tanwar and Aggarwal, S. K. 2019. Management of Sorghum Anthracnose caused by Colletotrichum graminicola (Ces.) Wilson. Int.J.Curr.Microbiol.App.Sci. 8(10): 1371-1371. doi: https://doi.org/10.20546/ijcmas.2019.810.159 